\title{
THE ROLE OF SOCIO-PSYCHOLOGICAL FEATURES OF THE PEDAGOGICAL COMMUNITY IN THE FORMATION OF THE SOCIAL PICTURE OF THE WORLD OF UKRAINIAN YOUTH
}

\section{Bielavina T. I.}

\section{INTRODUCTION}

In Ukraine, recently, there is a multidimensional process of coexistence and interaction of new ideologies, different cultures and their representatives. This determines the formation of a new social identity, positive and common to the Ukrainian society. Actively involved all strata of society in various activities, which are due to the emergence of new forms of ownership. Against the background of the construction of statehood, the inclusion of citizens in a new system of interpersonal relations, mediated, inter alia, by the building of democratic foundations of society and the development of a culture of civicism is intensified, that is, an intensive personality embedding into the versatile socio-cultural life of modern Ukraine takes place.

In such conditions, the formation of a general and social picture of the world of children, adolescents, youths, youth is carried out. In addition, their life benchmarks are determined. Traditionally, the main institutions of influence on the formation of a person are family and school. At the same time, almost two decades have been marked by a certain activity of a critical analysis of the domestic educational system, which does not manage to overcome the violent changes in public life, values and models of identification. In fact, education gradually loses value itself and becomes only a means of generating high incomes in the future, or, worse, a means of "waiting" for social hardship.

Partial formal and total informal commercialization of education, the gradual aging of the pedagogical corps of the state secondary school, the outflow of young, socially mobile educators, the emergence of social apathy of the share of teaching, even a certain marginalization of the educational community as a whole and its individual components led to a decrease in social efficiency and a reduction in prestige education.

Circumstances and problems that are subjectively perceived by young people as impediments to normal life can be defined as typical situations that simulate typical behaviors, whose manifestations are fixed in determining the typical strategy of a person, such as the ability and 
readiness for a particular choice and the ability to accept certain solution in accordance with the life benchmarks.

Usually the assimilation of norms and values of the actual social space is carried out by the older generation, which can provide young people with the necessary samples of adaptive behavior or through the targeted influence of professional socializers: teachers, educators, psychologists in the education system, social educators, social workers, etc. Therefore, in order to analyze the peculiarities of the pedagogical community and its role in shaping the social picture of the world and the living standards of young people in contemporary Ukraine, it is considered necessary to define a wide range of such problems.

\section{Socio-psychological characteristics of the pedagogical community in modern Ukraine}

During the changes in our state, the whole society at the same time was in a situation of dissonance in all its kinds and circumstances, which require the maximal updating of adaptive resources of the individual. This is especially true for young people who are most vulnerable and most often need social assistance.

In the defined conditions of the development of Ukrainian society and its future there was a problem of determining the socio-psychological specificity of the pedagogical community, its gradual partial marginalization, as well as clarifying the conditions and resources of the demarginerization of separate segments of the educational space on the one hand, and on the other - the role of the pedagogical community in the formation the social picture of the world and the life-marker of the next generation.

That is, the research search within this work is aimed at attracting attention and preliminary analysis of the problem of partial marginalization of the pedagogical community, its psychological components, in particular, the importance of the profession in limiting the resourcefulness of the subject of pedagogical activity, and reducing the effectiveness of its educational effect.

"Transfer of experience to the new generation is an ontological function of a social organism, which needs to be carried out with natural enthusiasm and genuine professional dedication”, V. Tatenko notes, analyzing the socio-psychological problems of reforming education ${ }^{1}$.

\footnotetext{
${ }^{1}$ Татенко В.О. Соціально-психологічні проблеми реформування освіти: спроба системнотипологічного аналізу // Наукові студії із соціальної та політичної психології. - 2005. - № 10 (13). C. 15-35.
} 
But the transition period in the reform of education turned out to be rather problematic and was accompanied by events that had somewhat negative consequences. Partial formal and total informal commercialization of education has led to the fact that commercial educational establishments received a competitive advantage in contrast to the general secondary school. The youngest, active, mobile, flexible group of educational services specialists directed their professional efforts towards non-state-owned educational institutions. This, in turn, led to the gradual aging of the pedagogical corps of the state secondary school, the departure of young, socially mobile educators from it, the emergence of social apathy of the share of teaching as an integrated community, and, to a degree, the marginalization of the teaching community as a whole and its individual components.

The above-mentioned resulted in the tendency to lose part of the layer of intellectuals and intellectuals who would not have nostalgic experiences with the past. Their main function (the transfer to the next generation of basic values and cultural standards within the cultural and normative system of modern society, the formation of a social picture of the world of the new generation) is partially limited to these trends.

Thus, the traditional conservatism of the education system as a function of preserving socially approved values and living standards, material difficulties at the present stage of the formation of Ukrainian statehood, lack of flexibility in the public sector to the introduction of new educational technologies, led to a decrease in social efficiency and a reduction in the prestige of education.

The problem of the influence of the profession on a person and a professional group has traditionally been studied as the relationship between activity and personality in the system of professions "human-human", profession and consciousness, but has not yet been studied in this context. The theoretical foundations of its development are well-known concepts and approaches: general psychological, psychological and pedagogical; socio-engineering, engineering-psychological, and professional studies, which are represented by the researches of E. Klimov², O. Malchazov².

Specifics of social or communicative professions are characterized by the advantage of situations with high emotional saturation and cognitive complexity of interpersonal communication. This requires a

\footnotetext{
${ }^{2}$ Климов Е.А. Психология профессионала. - М.: Педагогика, 1996. - 125 с.

${ }^{3}$ Малхазов О. Р. Психологія праці: навч. посібник для студ. вузів / О. Р. Малхазов. - Київ : Центр учбової літ. (ЦУЛ), 2010. - 206 с. : рис., табл.
} 
specialist significant personal contribution to establishing trust relationships and the ability to manage emotional tension in professional communication.

The professions of the type "human-human" include the so-called "social" or "communicative" professions, which are characterized by "constant intensive communication with colleagues, subjects of professional activity”, namely, managers at all levels, representatives of service occupations, medical workers, workers in the sphere of education (scientific and pedagogical workers of institutions of higher and secondary education, teachers, educators of kindergartens), psychologists, psychotherapists, psychiatrists and others. E. Klimov developed a fourlevel classification of professions on the basis of the subject, goals, means and conditions of work and introduced the concept of professions such as "human-human"1.

A. Pines and E. Aronson, examined the state of physical and emotional exhaustion and other manifestations of disharmony of experiences and behavior as a result of prolonged stay in emotionally difficult situations ${ }^{4}$.

In American psychology, the subject of the study was different - the concept of "engagement" proposed by C. Maslach. Its content characterizes the focus on labor and the positive attitude towards it, enthusiasm, vigor, and efficiency" ${ }^{5}$.

Features of professional stress, its causes and consequences at the employees of educational organizations were investigated by L.O. Kitaev-Smyk ${ }^{6}$. A.O.Rean and A.A. Baranov ${ }^{7}$, L.M. Karamushka ${ }^{8}$ and S.V. Mitina ${ }^{9}$, etc.

"The psychological specificity of stress depends both on external influences, and on the personal meaning of the purpose of the activity, an assessment of the situation in which the person is. Production situations can act not so much as a cause, but as a reason for the emergence of stressful workers. ... The true causes are hidden in personality characteristics: outlook and settings, needs and motives, goals, stereotypes

\footnotetext{
${ }^{4}$ Организационная психология: Учебник (под общей редакцией А.Б. Леоновой) / А. Б. Леонова, М. М. Абдуллаева, Т. Ю. Базаров и др. - ИНФРА-М Москва, 2013. - 429 с.

${ }^{5}$ Maslach, C., Jackson, S. E., Leiter, M. P. Maslach Burnout Inventory Manual (4 Edition). Palo Alto, California: Consulting Psychological Press, Inc., 1997. P. 46-71.

${ }^{6}$ Китаев-Смык Л. А. Психология стреса. - М.: Изд-во «Наука», 1983. - 368 с.

${ }^{7}$ Реан А. А., Баранов А. А. Факторы стрессоустойчивости учителей // Вопросы психологии, 1997. № 1. - C. 45-54.

${ }^{8}$ Карамушка Л. М. Психологія освітнього менеджменту: Навч. посібник. - К.: Либідь, 2004. - 424 с.

${ }^{9}$ Mitina S.V. The factors of emotional burnout of the teacher of the higher educational institution. Psychological and pedagogical problems of modern specialist formation. Warsaw: ANAGRAM Publishing House, 2017. № 1. P. 34-37.
} 
of perception, positions in interpersonal interaction, peculiarities of stress resistance or within personality dynamics" 10 .

The traditional conservatism of the school is defined by the needs of the profession, the formal representation of specific institutional values, and with it the personal rigor of the professional socialist, his nostalgic experiences regarding the past definite tasks of society, monoidalogy and logocracy become a significant obstacle for the older generation of teaching on the path of social adaptation to changes in contemporary Ukrainian society. Therefore, it is important to analyze the phenomenon of marginality and to identify the features of the relationship of limited resource of the subject of pedagogical activity and the peculiarities of the professional deformation of the teacher's personality.

So far, in defining the content of the concept of marginality in the practice of using the term itself, there are several disciplinary approaches: in sociology, social psychology, cultural studies, political science and economics, which adds quite a general, interdisciplinary character to the concept itself. The history of the emergence and functioning of the term «marginal» is relatively short, but its methodological universality each time determines a new content in the study of a variety of social processes. The term "marginal” (marginal - from the Latin margo - edge) was originally used to designate entries, marks on the fields; in another sense, it means "economically close to the limit, almost unprofitable". As sociologist he first began to use in his essay "Human Migration and the Marginal Man” (1928) American sociologist Park R.E. (1864-1944) ${ }^{11}$ This work initiated the formation of ideas about the type of "frontier" man, where the notion of marginality determined the position of individuals who are on the verge of two different, conflicting cultures.

By analogy, the post-Soviet era's teaching is at the crossroads of several cultures: the pre-Soviet (in the cultural resources of the family, the notions of knowledge as a model of the intelligentsia, in the values, ideological symbols of their own parents, grandparents), Soviet (within their own experience and their own history) post-Soviet (in new sociocultural landmarks, values), and cultures of the image of the future (in representations and expectations of a new generation). Modern teaching feels "moral confusion" that causes cultural crossings at all

\footnotetext{
${ }^{10}$ Кулик С.М. Психологічні проблеми професійної адаптації вчителів // Актуальні проблеми психології. Том 1.: Соціальна психологія. Психологія управління. Організаційна психологія/ За ред. МаксименкаС.Д., КарамушкиЛ.М. - К.: Інститут психології ім. Г.С. Костюка АПН України. Частина 2, 2001. - С. 201-204.

${ }^{11}$ Park R.E. Human migration and the marginal man // Amerikan Journal of Sociology. Chicago, 1928. Vol. 33. № 6. P. 881-893.
} 
levels, besides, it is still burdened with nostalgic experiences of past stability, certainty, regulation, total normatization of the "Soviet school", prevailing logocracy, and so on.

Socio-psychological adaptation in the conditions of sharp social changes in society can lead to a crisis of personality-role identity. The new situation of existence in society requires new knowledge, approaches, methods of socialization, it predetermines the necessity of pragmatic as the content of education, and the specifics of the means of pedagogical activity. The overcoming of the crisis of personality-role identity is through social and psychological adaptation on the group and personal levels.

The marginal status of the pedagogical community may be due to the marginal situation of the existence of a community (in our case pedagogical), the marginal person of the subject and the object of the educational process (teacher, learner or pupil), marginal group (as subjects, as well as objects of pedagogical activity), as well as the situation of overcoming the marginal crisis.

The state of marginality is due to the general crisis, so the main feature is its forcedness under the influence of external circumstances. Features of the modern socio-psychological specificity of the marginalization of the pedagogical community are determined by the loss of once high social professional status, social relations, value orientations of the most educated groups of people, people with high level of education: etc.

In the periods of social anomy, the absence of norms is accompanied by intensive social changes, the destruction of old norms in the absence of new, the formation of new foundations for the construction of social roles and, respectively, status positions. In general, this state determines the marginal status. Types of marginal positions are diverse. For example, the type of employment spread in the most difficult times of the early and mid-1990s, has led to the emergence of an uncertain set of employment: on the one hand, you need to be active, mobile, able to "earn", on the other - "hold something" in an institution, in a medical institution or an enterprise. A number of education professionals have mercilessed their work, some have lost their job in the specialty, for the most part, for many years, they were in a state of uncertainty about "work without pay".

A huge number of teachers went through the path of the "shuttle economy”, low-skilled work in the service sector, changing status from an educator to the "implementer" of goods in the market, etc., losing subjective identification with the pedagogical community, radically 
changing the content of socio-psychological guidance, breaking the social links The tricks that supported the previous social status.

Modern marginalized communities are built on social changes of the last decades from those "old" groups that already existed in the social space. The pedagogical community at the macro level may to some extent be regarded as marginal as the phenomenon of marginal social structure phenomena in connection with the reorganization or disorganization of social systems as a consequence of the general marginal character of the post-Soviet social space. Against the backdrop of radical changes in society and the construction of statehood and citizenship, questions of significance of the national language, new criteria for identification ("budgeter", "freelancer"), the question of the legitimacy of new institutions (shadow employment), etc., arises.

At the midi level, the marginalization of the pedagogical community is due to a change in the worst part of the socioeconomic status of teaching. Marginality is manifested as a phenomenon of the radical shift of the socio-occupational structure of society and the social status of large groups of the population as a result of the crisis and subsequent reforms. At the forefront is the problem of the need for the formation of new social features of subjects of pedagogical activity, capable of occupying new positions in the labor market in the context of changing the socioeconomic context (educational institutions of various forms of ownership, economic censorship for students, etc.).

At the micro level, the marginal status of the individual or group in the state of uncertainty in the intermediate marginal situation that forms the marginal person by R. Park ${ }^{12}$ needs special attention. The marginal situation of cultural, ideological shock, economic deprivation has a psychoactive effect and causes stress, frustration and other uncomfortable mental states that exacerbate psychological burnout, professional deformation. Such a situation for a part of the pedagogical corps becomes a significant obstacle to the integration into new conditions of society's life. Cognitive dissonance, moral dichotomy, intrapersonal conflict, loss of previous benchmarks and the absence of new forms in some of the features of "man of two worlds": anxiety, rigidity, loneliness, uncertainty of personal value and interpersonal relationships, fear of risk, etc ${ }^{13}$.

The peculiarity of the content of goals and objectives, the specific requirements, the particularity of the contingent of students of the so-

\footnotetext{
${ }^{12}$ Park R.E. Human migration and the marginal man // Amerikan Journal of Sociology. Chicago, 1928. Vol. 33. № 6. P. 881-893.

${ }^{13}$ Там само.
} 
called elite on the economic grounds of educational institutions on the one hand, and the specific conditions and regime requirements of the life of the so-called closed educational institutions on the other, repeatedly reinforce the isolation of groups (as specialists and pupils) from the broader society, substantially impoverishes the variability of social situations of their mutual influence and the system of relations of the subject in social reality. In addition, they significantly remind the system of referential interpersonal relationships, preventing the adequate socialization of the individual.

The local community strives to close itself, inclines itself to a system of personalized relationships that are closed to the outside world (family, intimate circle of communication, corporate group, employees and pupils of law-enforcement institutions). The influence of such a community is determined, firstly, by the power of the group (the normative influence, the result of which is sustainability), and secondly, the desire to coincide with the social determinations of reality, which are based, first of all, on consent (the information influence, the result of which is internalization). Group pressure provides social predictability, arming its means of control, which are determined by the degree of power.

In localized communities, the relationship between teachers and pupils is characterized by a predominantly role-based approach to assessing each other. The significance of the teacher for the pupil is due, first of all, to the degree of the power of an adult in the conditions of relative isolation from the broader society of closed educational institutions, on the other hand, the role of a specialist in providing educational services or the degree of his economic discrimination in private, so-called, elite educational institutions .

Focusing on the educational-disciplinary model of education as part of a nostalgic pedagogical community in the past inevitably leads to a pronounced discrepancy between functional-role expectations, mutual rejection, dissatisfaction with the style of interaction and communication in the community at an educational institution. This leads to specific socio-psychological phenomena inherent in marginalized groups: group embezzlement, psychological isolation of the individual in the middle of the group, corporate identity, violation of communication, destruction of unity. 


\section{A social picture of the world and life orienters of the pupillary youth and student youth of Ukraine}

The modern social reality, the reappraisal of spiritual and material values, the breaking of stereotypes, the destruction of myths, property stratification in society, the loss of values that seemed stable even yesterday, the decline in the reliability of social guarantees causes aggravation of problems in the youth environment, its social disorientation, social passivity of youth, manifestation of absenteeism, apolitical, nonconformism in relation to the values of the majority, the priority of consumer orientations over creative ones.

The generalization of only some of the results of the study to determine the socio-cultural and socio-psychological portrait of pupillary youth and student youth in the southern and eastern regions of Ukraine allowed to outline the spectrum of the problem field of its life.

In the course of the survey, two youth groups aged 16-17 (n-360) and 18-23 (n-360) were interviewed. The choice of age boundaries is conditioned by the relative connection of the age and certain formal definitions of the social status of respondents: 16-17 years old - receiving secondary education for the overwhelming majority of young people in general and special educational establishments, the period of professional self-determination; 18-23 years old - a period of professional development, therefore, students' youth were questioned.

The general characteristics of modern youth make it possible to determine the indicators of the distribution of responses from various aspects of social life and attitudes toward it: trust - distrust, optimism and pessimism, level of satisfaction with life and hope for the better.

The distribution of answers to the question "Do you trust people around you?" Indicates the relative social loyalty of respondents. "Yes" answered $44.2 \%$ of pupils, 30.5\% - students. Uncertainty and distrust in the social environment are felt by almost a third of students (28.7\%) who answered "no" definitely, as well as $18.8 \%$ of pupils. That is, the level of depersonalized trust in the social environment and the degree of critical assessment of the social environment and its influences to a degree depends on the age and educational level.

A higher level of trust, traditionally associated with the positive direction of expectations and claims (44.2\%), on the one hand, and relatively low criticality in the assessment of society (18.8\%) on the other, is inherent in early adolescence. It can be a source of socializing influences as a positive, prosocial content, and vulnerability to the effects 
of negative meaning. The high significance of communication with peers, the trust and reference of peer evaluative judgments on various issues of personal and social life are an important resource in the development of socializing programs.

For a more complete understanding of different segments of the problem field of youth life, it is necessary to determine the peculiarities of its interaction with social reality, typical mental states, the usual ways of responding to the problems, in the context of changing the social, economic and cultural context in Ukraine. Answers to the question "What state do you experience most often?" Allowed to determine the most typical psychological reactions in the present.

The leaders in the most typical psychic states are "expectations for the better" and "determination to improve their lives". At the same time, concerns about typical fatigue, loneliness, anxiety, irritation, which indicate discomfort, a state of psychological danger, that is, the need for help, support, are typical.

Answers to the question "Do you expect change for the better in your life?” Also indicate a general positive mood, some optimism, expectations of a better future (81.2\% of the pupils answered yes, $77.1 \%$ of students). Optimism is inherent in the overwhelming majority of the researchers, gives hope for overcoming psycho-traumatic situations, the search for and use of resources for adequate adaptation and optimal strategies for integration into the modern Ukrainian society. But an insufficiently critical evaluation of a possible future reveals yet few justified expectations.

Table 1

\begin{tabular}{|l|c|c|}
\hline \multirow{2}{*}{ Distribution by answers } & \multicolumn{2}{|c|}{ \% of the number of responses } \\
\cline { 2 - 3 } & $\begin{array}{c}\text { pupils } \\
\text { 16-17 years old }\end{array}$ & $\begin{array}{c}\text { students } \\
\mathbf{1 8}-\mathbf{2 3} \text { years old }\end{array}$ \\
\hline loneliness & 28,7 & 28,2 \\
\hline waiting for the best & 41,4 & 44,3 \\
\hline anxiety & 24,3 & 20,1 \\
\hline irritation & 21,5 & 24,7 \\
\hline confusion & 12,7 & 14,4 \\
\hline resolve to improve life & 37,0 & 33,9 \\
\hline compassion for people & 22,7 & 7,2 \\
\hline fatigue & 20,4 & 30,5 \\
\hline patience and humility & 14,4 & 8,6 \\
\hline other & 7,7 & 5,2 \\
\hline
\end{tabular}


The problem that troubles respondents is united on the question "Which of the following problems worry you personally?". Problems are grouped into blocks of 7 allegations (socio-legal, health, economic, relationships).

Indisputably, the source of anxiety and anxiety in the social-legal block is the lack of jobs (33\% is the average for pupils and students), corruption in the authorities (29\%) and high crime rates (23\%). It can be used as a content component in the development of correctional tools aimed at optimizing integration into the society. Interesting social-role dynamics is observed in relation to the problems: older respondents are concerned about the lack of jobs, and the adolescents are not looking for a job in the future.

Different answers look depending on the age category: in relation to corruption (students - 29,1\%, pupils - 19,3\%) and high crime rate (students - 14,3\%, pupils -23\%). Unfortunately, only a small part of respondents are concerned about the lack of education as a possible resource of a successful career and planning of the future.

Respondents who are current for the present (average): the problems of spreading HIV / AIDS (43.6\%), the spread of drug addiction (29.3\%) and alcoholism (24.5\%) among young people, sexual intercourse, albeit confusing, but not attributed to those that require considerable attention.

The representation of young people about a healthy lifestyle allows you to navigate the semantic space of health culture, but have not yet differentiated superficiality. With age, the attitude to such social aspects ceases to be abstract and the health problem is personalized, becoming the health status of "my and my family members". Young people are surely aware that a large number of "normal" people are smoking, drinking, eating badly and not doing sports. These stereotypes essentially reduce the value of a healthy lifestyle. Attention to ecology is insignificant, but with age it grows (pupils - 12,7\%, students - 24,1\%).

This state of affairs can be explained either by the lack of special information and education materials on a particular topic or by the lack of access to such materials.

The actual sphere of the problems is almost for all respondents the sphere of social contacts: relations in the family (pupils - $24.3 \%$, students $-39.2 \%$ ), friends and peers or loneliness (pupils - $24.5 \%$, students $-38.7 \%$ ), relations with the opposite sex (pupils - $13.2 \%$, students $-16.0 \%$ ), fears do not meet expectations, appearance (pupils $33.8 \%$, students $-38.1 \%$ ). There is a need to learn to communicate, find 
common ground with different people, be assertive, be able to tell the truth, overcome discomfort in communication.

The answers to the question "To whose help you are counting on the most difficult things in the first place?” Most accurately characterize: typical resources of solving problems of a person, typical ways of planning it for the future, externality - internality of adaptive strategies. The obtained results testify to some externality of a significant part of the respondents, that is, they are typical for them - the orientation of expectations in the outside world, the expectation of good luck, friends, parents, even God, and not resorting to their own resources to overcome the difficult circumstances in their lives.

The majority of respondents express confidence that their future depends on them, which is a natural age-old feature of this sample of respondents. This indicator is somewhat lower among students, which is explained by the acquired life experience. Hope for parents, friends, God, the state is more likely to be associated with the peculiarities of the social situation in which their life unfolds.

Table 2

\begin{tabular}{|c|c|c|}
\hline \multirow{2}{*}{ Distribution by answers } & \multicolumn{2}{|c|}{$\begin{array}{l}\% \text { of the number } \\
\text { of responses }\end{array}$} \\
\hline & $\begin{array}{c}\text { pupils } \\
16-17 \text { years old }\end{array}$ & $\begin{array}{c}\text { students } \\
\text { 18-23 years old }\end{array}$ \\
\hline only to myself & 56,4 & 28,2 \\
\hline parents and relatives & 45,3 & 44,3 \\
\hline friends and acquaintances & 21,5 & 33,9 \\
\hline beloved person & 12,2 & 17,2 \\
\hline I rely on good luck & 7,2 & 30,5 \\
\hline I hope only for God & 6,1 & 8,6 \\
\hline other & 1,1 & 5,2 \\
\hline
\end{tabular}

It is clear that pupils' youth and students count on the care of family members, since they do not yet have their own material sources of independent life, but these indicators also indicate the subjective importance of the family as a universal value. The family, being the highest value and resource for achieving meaningful goals, can at the same time serve as an institution for restoring the deficit of depersonalized trust in the world, the social environment, as well as depersonalized violence, social pressure in radical social reality.

Study of the guidelines concerning the conditions for achieving success allows to determine the content and level of motivation for 
achieving success, updating the creative potential of the individual, positive self-affirmation of the individual, revealing the image of a successful person in the consciousness of the subjects.

To a certain extent, the distribution of answers to the question "What is the main guarantee of life's success today?" Can help. Respondents prefer utilitarian, pragmatic conditions for success: money, influential people, ability to adapt, but prevails all the same idea that success can be achieved through reason.

Meanwhile, the "privatization of the public space" inherent in our modern life is due to the "privatization of useful people", the use of them as a scarce resource by transforming them into friends, "friends of our friends”, family members.

Table 3

\begin{tabular}{|l|c|c|}
\hline \multirow{2}{*}{\multicolumn{1}{c|}{ Distribution by answers }} & \multicolumn{2}{c|}{ \% of the number of responses } \\
\cline { 2 - 3 } & $\begin{array}{c}\text { pupils } \\
\text { 16-17 years old }\end{array}$ & $\begin{array}{c}\text { students } \\
\mathbf{1 8}-23 \text { years old }\end{array}$ \\
\hline intelligence & 66,9 & 74,1 \\
\hline physical strength & 17,7 & 15,5 \\
\hline money & 67,4 & 74,7 \\
\hline humility & 6,1 & 3,4 \\
\hline the presence of the patron saint & 8,3 & 6,3 \\
\hline acquaintance with influential people & 33,7 & 37,9 \\
\hline the ability to adapt & 39,2 & 42,5 \\
\hline $\begin{array}{l}\text { knowledge and observance of } \\
\text { traditions and unwritten laws }\end{array}$ & 7,2 & 4,0 \\
\hline other & 3,3 & \\
\hline
\end{tabular}

Thus, such data on living standards, concerning various aspects of social life among pupils youth and students, lead to serious reflections, as they demonstrate the unduly small role played in this important process by such competent sources of information as teachers, teachers, doctors, school psychologists, social educators, social workers.

Thus, the dependent position of a person in the formally defined limits of the "teacher-child" system in a general education school, vocational education institutions dramatically reduces the child's personal significance for a professional socialist. And this limits the capabilities of the developing person to be fully represented in the minds of a referent adult or adult community. 
"The process of socialization reveals and constitutes the peculiar power of socializing adults over the child”, writes V.O. Vasyutinsky ${ }^{14}$, who "predetermine its development through joint activities ... support for internalizational and adaptive forms of socialization ... at the same time, these socializing adults restrict the individual in development, close other opportunities to him, restrain him in his own efforts".

The consistent implementation of the formal functional-role approach to organizing its interaction with the micro-institution of the institution forces the teacher to act within the limits of the norms of the system of relationships that spontaneously forms between pupils, between employees, between pupils and adults. They contribute to the establishment of such an informal structure of communities, the nature of which may directly contradict the educational goals.

Negative effects of the marginalization of the pedagogical community are particularly acute in localized groups. For example, in orphanages, boarding schools, and vocational-specialized boarding schools there is a fairly pronounced confrontation between polar strata, which practically does not reduce the intensity of communication between their representatives with each other. This becomes possible because in closed communities of this type daily close, although the confrontational contact of everyone with everyone is the norm of intragroup life. In such educational institutions, the informal rights and responsibilities of each of the intragroup strata are clearly defined in the unwritten set of rules and norms of "other life".

Despite the well-known features of the informal intragroup structure of closed communities, the common features of the intra-group "device" allow us to talk about the socio-psychological similarity of such groups. The complete concentration of informal power in the hands of a clear minority, discriminatory in its content and frankly antihuman forms of influence of this minority on the intragroup majority, "caste” by its nature, intragroup status differentiation, a high degree of personalization of the "elite" in the minds of the depersonalized major mass of the community is the main indicators of the life of groups of different localization ${ }^{15}$.

This requires consideration of the entire set of such communities as marginal as groups that can, under appropriate circumstances, turn into corporate groups with a pronounced asocial orientation.

\footnotetext{
${ }^{14}$ Васютинський В.О. Інтеракційна психологія влади. - К.: Вид-во Київ. славіст. ун-ту, 2005. - 492 с.

15 Кондратьев М. Ю. Социальная психология закрытых образовательных учреждений. - СПб.: Питер, 2005 - 628 с.
} 
It will be important to direct the socializing influence in such a way that, for example, to form personal responsibility, increase the self-esteem of a young person, her confidence in her own ability to achieve something significant or overcome something unnecessary.

\section{CONCLUSIONS}

The educational system is traditionally the leading institution of socialization and has specific features: the purposeful nature of the impact on the restoration of the existing social system (conservatism), the existence of a unified ideal model of socialization (unification), the temporality of influence, the existence of the corps of professional socializers.

Formation of the social picture of the world in the process of translating relevant for a certain historical period of knowledge is carried out in the system of interaction of the student with a professional socializer.

The pedagogical community represents specific institutional values rather formalized and to some extent anonymous, which determines the narrowing of the subjective significance of the educator for the pupil. The degree of subjective significance of the personality of the teacher, his reference for the child, the adolescent, the teenager distributes to him the range of variations of the picture of the world.

The main issues in the development of a particular problem are the active search for opportunities and ways of demarganizing the community or the individual, which involves a concentration of efforts to narrow the boundaries of the "marginal breakthrough", outlining the constructive direction of the development of a modern pedagogical community that can change the state of affairs in a marginal social situation.

The main source of information on issues of personal concern and concern for most teens, adolescents and young people are friends, peers, acquaintances, family members, and others like that. The second most powerful source of information is television, radio, periodicals. The third according to the rating (but with low indicators) is the teacher's source of information for schoolchildren, although it is he who has to play one of the most important roles in the life of a teenager, but with age his role naturally reduces in favor of special literature, which goes on to the fore in the student's period.

Unfortunately, the role of a professional socialist, educator in the process of informing on these issues is insignificant. 


\section{SUMMARY}

The signs of the traditionally leading institution of socialization are defined: conservatism, unification, limitation of influence over time, the existence of the corps of professional socializers. Formalized representation of specific institutional values by the pedagogical community causes the subjective significance of the teacher to narrow the pupil, his role in shaping the social picture of the child's world. It is emphasized the importance of a detailed study of the problem of marginalization, conditions and resources of the demarginalization of the pedagogical community and its separate segments.

Demifologization of views on the historical past, the loss of the mono-ideological conviction of youth causes aggravation of problems in the youth environment, its social disorientation, social passivity of youth, extreme manifestations of politicization or apolitical, radicalization and nonconformism in relation to the values of the majority, the priority of consumer orientations over creative ones. Some results of the research are summarized in order to determine the socio-cultural and sociopsychological portrait of modern Ukrainian youth through a mass survey in the southern and eastern regions of Ukraine, which allowed to outline the spectrum of the problem field of its life.

\section{REFERENCES}

1. Васютинський В.О. Інтеракційна психологія влади. - К.: Вид-во Київ. славіст. ун-ту, 2005. - 492 с.

2. Карамушка Л. М. Психологія освітнього менеджменту: Навч. посібник. - К.: Либідь, 2004. - 424 с.

3. Китаев-Смык Л.А. Психология стреса. - М.: Изд-во «Наука», 1983. $-368 \mathrm{c}$.

4. Климов Е.А. Психология профессионала. - М.: Педагогика, 1996. -125 c.

5. Кондратьев M. Ю. Социальная психология закрытых образовательных учреждений. - СПб.: Питер, 2005 - 628 с.

6. Кулик С.М. Психологічні проблеми професійної адаптації вчителів//Актуальні проблеми психології. Том 1.: Соціальна психологія. Психологія управління. Організаційна психологія / За ред. Максименка С.Д., Карамушки Л.М. - К.: Інститут психології ім. Г.С. Костюка АПН України. Частина 2, 2001. - С. 201-204.

7. Малхазов О.Р. Психологія праці: навч. посібник для студ. вузів / О.Р. Малхазов. - Київ : Центр учбової літ. (ЦУЛ), 2010. 206 с. : рис., табл. 
8. Организационная психология: Учебник (под общей редакцией А.Б. Леоновой) / А.Б. Леонова, М.М. Абдуллаева, Т.Ю. Базаров и др. - ИНФРА-М Москва, 2013. - 429 с.

9. Реан А.А., Баранов А.А. Факторы стрессоустойчивости учителей // Вопросы психологии, 1997. - № 1. - С. 45-54.

10. Словник іншомовних слів. К., 1975. С. 413.

11. Социология образования перед новыми вызовами («круглый стол») // СОЦИС. 2000. № 6. С. 65-66.

12. Татенко В.О. Соціально-психологічні проблеми реформування освіти: спроба системно-типологічного аналізу // Наукові студії із соціальної та політичної психології. - 2005. - № 10 (13). C. $15-35$.

13. Maslach, C., Jackson, S. E., Leiter, M. P. Maslach Burnout Inventory Manual (4 Edition). Palo Alto, California: Consulting Psychological Press, Inc., 1997. P. 46-71.

14. Mitina S.V. The factors of emotional burnout of the teacher of the higher educational institution. Psychological and pedagogical problems of modern specialist formation. Warsaw: ANAGRAM Publishing House, 2017. № 1. P. 34-37.

15. Park R.E. Human migration and the marginal man // Amerikan Journal of Sociology. Chicago, 1928. Vol. 33. № 6. P. 881-893.

\section{Information about the author:} Bielavina T. I. $\mathrm{PhD}$ in Psychology, Associate Professor at the Department of Psychology and Pedagogy of the Scientific and Humanitarian Institute of the V. I. Vernadsky Taurida National University 